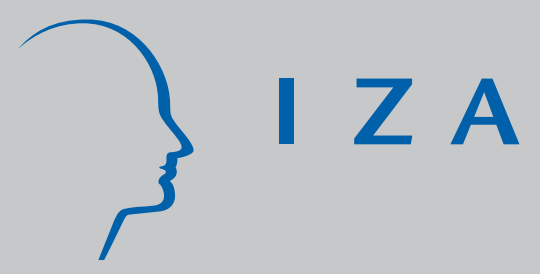

IZA DP No. 3446

Occupational Selection in Multilingual Labor Markets

Núria Quella

Sílvio Rendon

April 2008 


\title{
Occupational Selection in Multilingual Labor Markets
}

\author{
Núria Quella \\ ITAM, Mexico \\ Sílvio Rendon \\ Stony Brook University \\ and IZA
}
Discussion Paper No. 3446
April 2008

\author{
IZA \\ P.O. Box 7240 \\ 53072 Bonn \\ Germany \\ Phone: +49-228-3894-0 \\ Fax: +49-228-3894-180 \\ E-mail: iza@iza.org
}

\begin{abstract}
Any opinions expressed here are those of the author(s) and not those of IZA. Research published in this series may include views on policy, but the institute itself takes no institutional policy positions.

The Institute for the Study of Labor (IZA) in Bonn is a local and virtual international research center and a place of communication between science, politics and business. IZA is an independent nonprofit organization supported by Deutsche Post World Net. The center is associated with the University of Bonn and offers a stimulating research environment through its international network, workshops and conferences, data service, project support, research visits and doctoral program. IZA engages in (i) original and internationally competitive research in all fields of labor economics, (ii) development of policy concepts, and (iii) dissemination of research results and concepts to the interested public.
\end{abstract}

IZA Discussion Papers often represent preliminary work and are circulated to encourage discussion. Citation of such a paper should account for its provisional character. A revised version may be available directly from the author. 
IZA Discussion Paper No. 3446

April 2008

\section{ABSTRACT \\ Occupational Selection in Multilingual Labor Markets}

In multilingual labor markets agents with high proficiency in more than one language may be selected into occupations that require high levels of skill in communicating with customers or writing reports in more than one language. In this paper we measure this effect in Catalonia, where two languages, Catalan and Spanish, coexist. Using census data for 1991 and 1996, and controlling for endogeneity of Catalan knowledge, we find that proficiency in speaking, reading and writing Catalan reinforces selection into communication intensive jobs/positions such as entrepreneurial, trade, and service activities; white-collar occupations; and permanent employment. Interestingly, the effect of language on occupational selection is stronger for women than for men.

JEL Classification: J24, J61

Keywords: occupational selection, language, labor markets

Corresponding author:

Sílvio Rendon

Economics Department

Stony Brook University

Stony Brook, NY 11794-0001

USA

E-mail: srendon@ms.cc.sunysb.edu

\footnotetext{
*All errors and omissions are only ours.
} 


\section{Introduction}

Occupational selection has been explained by individuals' comparative advantage: people self-select into jobs at which they perform relatively better and therefore earn more (Willis and Rosen 1979). Language skills are a special form of human capital (Chiswick and Miller 2002) that is required relatively more in some jobs and consequently may also determine what occupations individuals prefer, particularly in multilingual economies. Thus, language knowledge may influence self-selection into occupations, activities and types of work that are intensive in communication, such as providing customer service or writing reports.

Catalonia's multilingual labor market, in which all labor force is proficient in Spanish, while an important proportion is proficient in Catalan, ${ }^{1}$ lends itself well for an in-depth analysis of the effects of language knowledge on occupational selection.

We find that for individuals born outside Catalonia reading and speaking as well as writing Catalan significantly reinforce occupational selection into communication intensive jobs/positions such as entrepreneurial, trade, and service activities, and white-collar occupations. Language knowledge also favors selection into permanent employment. These effects are stronger for women than for men.

\section{Data}

We first extract two samples of 250,000 randomly selected individuals from census data for 1991 and 1996, provided by the Catalan and Spanish National Statistical Institutes (IDESCAT-INE). These datasets contain information on personal attributes such as gender, age, marital status, schooling, place of residence, place of birth, number of years in Catalonia, occupational status, and knowledge of Catalan. We then combine this information with data at the municipality level, to capture the external-

\footnotetext{
${ }^{1}$ Because Catalan has a lower status than Spanish (Castilian), we have characterized Catalonia's labor market not as bilingual, but as multilingual, a more general and inclusive term. See Rendon (2007) for a more detailed discussion on language in Catalonia's economy.
} 
ity effects of residing in areas with widespread Catalan knowledge. We further restrict the sample to parents and children between the ages of 16 and 60, born in Spain but not in Catalonia, and participating in the labor force. Thus, the final sample contains 47,053 individuals for year 1991, and 69,043 for 1996 .

[Table 1 here]

Descriptive statistics for all variables by Census year and gender are presented in Table 1. Occupational variables are ordered by occupation, activity and type of work. We single out classifications that require more communication skills and, therefore, a higher level of proficiency in Catalan. White collar occupations as well as Services, and Government and Education absorb relatively more women than men. However, there are no important gender differences among individuals working in Trade. Finally, there are relatively more male than female entrepreneurs, but relatively more female than male temporary workers.

We class individuals who claim to understand and either only read or only speak Catalan as having a basic level of Catalan knowledge; individuals who report to read and speak are in the intermediate level; while those who can also write belong in the advanced level. Notice that women, who were less proficient in Catalan than men in 1991, overtake them in 1996.

Individuals in the sample are on average relatively old (around 43), with a growing level of education, especially women, and mostly married. The proportion of people affected by the Normalization process ${ }^{2}$ is growing over time for both genders, but more so for women, who overtake men in 1996. On average, individuals in the sample arrived to Catalonia at the end of the sixties, 25 years prior to the censuses, and mainly from Andalusia. Most of them live in municipalities where people are proficient in Catalan, born in Catalonia, and work in services.

\footnotetext{
${ }^{2}$ In 1983, the Catalan Government introduced the "Normalization policy" (normalització), which extends the use of Catalan to all official levels, including primary and secondary education.
} 


\section{Estimation Results}

Using these Census samples, we perform a discrete choice estimation corrected to account for language endogeneity, as language may be determined together with the occupational decision. First, we estimate a probit model for the probabilities of an individual exhibiting either the intermediate or the advanced level of proficiency in Catalan for 1991 and 1996, and for males and females separately. As individuals in the sample were not born in Catalonia, they are more likely than locals to have faced a language knowledge decision. We use as exogenous sources of variation for language proficiency information on Catalan knowledge in the municipality of residence; whether the individual was affected by the "Normalization policy;" whether the individual arrived to Catalonia before age 10; number of years since migration; an interaction term between years since migration and whether the individual arrived before age 10; and origin variables such as whether the individual was born in Andalusia or in other Catalan-speaking regions of Spain. ${ }^{3}$ These variables represent the externality effect the community of residence has on the individuals' level of Catalan knowledge, and the individual's exposure to schooling in Catalan and to the Catalan economy. Therefore, they should directly affect the individual's proficiency in Catalan, but not the probability of occupational selection.

In a second stage, using the estimated parameters of the language selection equation, we proceed to estimate the probability of being selected into white-collar occupations; trade, service and public sector activities; and entrepreneurial and temporary employment conditional on a given Catalan proficiency level. Additional control variables in this equation are: age, schooling, marital status, province of residence, percentage of individuals employed in the municipality of residence and, of these, percentage in the service sector. Table 2 shows the estimated discrete effects for the two levels of Catalan knowledge.

\footnotetext{
${ }^{3}$ The estimation results of the first stage, available upon request, are very similar to those obtained in Rendon (2006).
} 
[Table 2 here]

Clearly, all estimated discrete effects, regardless of gender and census year, are significantly different from zero. Thus, language knowledge is shown to decisively influence individuals' self-selection into occupations, activities and types of work that are intensive in communication.

To begin with, the contribution of language to the probability of an individual selecting a white collar occupation is high, around 10 percent on average, for both genders and census years within either level of language proficiency. This contribution is always higher for women.

We can also see a differentiated pattern according to gender in the contribution of language to individuals selecting an activity for both levels of language knowledge. Regardless of language proficiency level and census year, the contribution of language to men selecting Trade is higher than for women; whereas women are more influenced by their level of language proficiency when selecting into Government and Education and, to a lesser extent, Services.

With regards to an individual's type of work, and regardless of language level, language knowledge helps men more than women to be Entrepreneurs. It also reduces significantly the probability to be Temporary workers, more for men than for women in 1991, but more for women than for men in 1996.

In sum, in all of these estimations language proficiency does make a significant difference in occupational selection, increasing the probability that individuals engage in jobs in which communicative skills are needed, such as services, trade, government, education, as entrepreneurs and permanent workers.

\section{Conclusions}

For a sample of Spanish individuals who were not born in Catalonia, language knowledge in all proficiency levels significantly reinforces occupational selection into com- 
munication intensive jobs and positions such as entrepreneurial, trade, and service activities and white-collar occupations. Language knowledge also contributes to selection away from temporary employment and into permanent employment. Interestingly, these effects are stronger for women than for men.

\section{References}

Chiswick, B. R. and Miller, P. W. (2002), 'Immigrant Earnings: Language Skills, Linguistic Concentrations and the Business Cycle.', Journal of Population Economics 15, 31-57.

Rendon, S. (2007), 'The Catalan Premium: Work and Language in Catalonia', Journal of Population Economics 20(3), 669-686.

Willis, R. and Rosen, S. (1979), 'Education and Self-Selection', Journal of Political Economy 87(5), S7-S36. 
Table 1: Summary Statistics

\begin{tabular}{|c|c|c|c|c|}
\hline \multirow{2}{*}{$\begin{array}{l}\text { Census Year } \\
\text { Gender }\end{array}$} & \multicolumn{2}{|c|}{1991} & \multicolumn{2}{|c|}{1996} \\
\hline & Men & Women & Men & Women \\
\hline \multicolumn{5}{|l|}{ Occupational Variables } \\
\hline Occupation: \% in White Collar & 30.1 & 49.8 & 38.0 & 60.7 \\
\hline Activity: \% in Trade & 27.0 & 27.0 & 28.0 & 28.2 \\
\hline Activity: \% in Services & 15.0 & 43.6 & 17.0 & 44.4 \\
\hline Activity: \% in Government and Education & 5.7 & 11.2 & 8.3 & 14.6 \\
\hline Type of work: \% Entrepreneurs & 6.0 & 3.6 & 7.3 & 4.8 \\
\hline Type of work: \% Temporary Workers & 22.88 & 34.74 & 24.79 & 32.08 \\
\hline \multicolumn{5}{|l|}{ Catalan Knowledge } \\
\hline Basic & 69.8 & 72.7 & 59.3 & 49.8 \\
\hline Intermediate & 19.9 & 17.5 & 26.8 & 27.0 \\
\hline Advanced & 10.3 & 9.8 & 13.9 & 23.2 \\
\hline \multicolumn{5}{|l|}{ Socio-Demographic Variables } \\
\hline Age & 42.4 & 42.5 & 44.3 & 41.5 \\
\hline Education & 6.4 & 5.7 & 7.3 & 7.7 \\
\hline$\%$ Married & 82.3 & 85.6 & 81.2 & 71.8 \\
\hline$\%$ Normalized & 0.8 & 0.6 & 2.2 & 3.6 \\
\hline Years Since Migration & 25.0 & 24.8 & 28.4 & 26.8 \\
\hline$\%$ Born in Andalusia & 64.0 & 62.4 & 63.0 & 57.9 \\
\hline \multicolumn{5}{|l|}{ Municipality Variables: } \\
\hline \% Advanced Catalan Knowledge & 37.4 & 37.5 & 43.9 & 44.5 \\
\hline$\%$ Catalan-born & 63.9 & 64.0 & 65.4 & 65.8 \\
\hline$\%$ Work in Services & 51.8 & 52.1 & 58.1 & 59.1 \\
\hline
\end{tabular}

Table 2. Occupation and Activity according to Language Proficiency Level Standard errors in small fonts

\begin{tabular}{|c|c|c|c|c|c|c|c|c|}
\hline \multirow{3}{*}{$\begin{array}{l}\text { Language Skills } \\
\text { Census Year } \\
\text { Gender }\end{array}$} & \multicolumn{4}{|c|}{ Intermediate } & \multicolumn{4}{|c|}{ Advanced } \\
\hline & \multicolumn{2}{|c|}{1991} & \multicolumn{2}{|c|}{1996} & \multicolumn{2}{|c|}{1991} & \multicolumn{2}{|c|}{1996} \\
\hline & Men & Wom. & Men & Wom. & Men & Wom. & Men & Wom. \\
\hline \multicolumn{9}{|l|}{ Occupation: } \\
\hline \multirow[t]{2}{*}{ White Collar } & 10.08 & 14.03 & 8.93 & 13.35 & 9.08 & 18.26 & 11.25 & 12.66 \\
\hline & 2.96 & 3.76 & 2.50 & 4.59 & 2.81 & 5.80 & 3.65 & 5.63 \\
\hline \multicolumn{9}{|l|}{ Activity: } \\
\hline \multirow[t]{2}{*}{ Trade } & 3.75 & 1.53 & 3.88 & 0.23 & 0.10 & -2.65 & -0.35 & -6.39 \\
\hline & 0.70 & 0.32 & 0.61 & 0.04 & 0.02 & 0.68 & 0.08 & 1.59 \\
\hline \multirow[t]{2}{*}{ Services } & 2.12 & 3.98 & 2.80 & 1.93 & 7.11 & 13.44 & 9.02 & 11.55 \\
\hline & 0.71 & 0.80 & 0.95 & 0.33 & 1.94 & 3.29 & 2.24 & 3.30 \\
\hline \multirow[t]{2}{*}{ Gov't and Education } & 1.73 & 2.84 & 1.83 & 4.54 & 5.84 & 8.87 & 7.31 & 12.04 \\
\hline & 1.17 & 2.64 & 1.16 & 3.09 & 2.88 & 5.05 & 3.00 & 5.43 \\
\hline \multicolumn{9}{|l|}{ Type of work: } \\
\hline \multirow[t]{2}{*}{ Entrepreneur } & 2.48 & 0.47 & 2.18 & 0.74 & 0.72 & 0.38 & 1.25 & -0.35 \\
\hline & 0.90 & 0.21 & 0.70 & 0.26 & 0.28 & 0.16 & 0.44 & 0.14 \\
\hline \multirow[t]{2}{*}{ Temporary Worker } & -1.98 & -1.78 & -3.13 & -0.17 & -0.48 & -1.04 & -0.35 & -1.20 \\
\hline & 0.72 & 0.46 & 0.89 & 0.04 & 0.19 & 0.33 & 0.12 & 0.41 \\
\hline
\end{tabular}

